\title{
Species diversity and community structure in trap-nesting bees in Southern Brazil ${ }^{1}$
}

\author{
Maria Luisa Tunes BUSCHINI* \\ Departamento de Biologia, Universidade Estadual do Centro Oeste, Rua Presidente Zacarias 875, Guarapuava \\ (PR), 85010990, Brazil
}

Received 28 April 2005 - revised 8 August 2005 - accepted 15 August 2005

\begin{abstract}
The species diversity and community structure of trap-nesting bees in the Parque Municipal das Araucárias in Southern Brazil was studied during 2 years. Three different habitats (Araucaria forest, swamp and grassland) were investigated in terms of abundance, richness, diversity and similarity of bee communicites. A total of 120 nests of 11 species were collected. The largest abundance of individuals and species richness was found for the family Megachilidae. The most abundant species were Centris tarsata, Megachile brasiliensis and Colletes sp. Intermediate species were C. tarsata, M. brasiliensis, Colletes sp, Epanthidium nectarinioides, Megachile (Dactylomegachile) $\mathrm{sp}_{1}$, Anthodioctes claudii, Megachile $\mathrm{sp}_{1}$ and Megachile $\mathrm{sp}_{2}$. Megachile (Austramegamegachile) fiebrigi, Xylocopa (Neoxylocopa) augusti and Megachile (Moureapis) $\mathrm{sp}_{1}$ were the rare species. Swamp habitat yielded the greatest abundance and diversity of bee species. The similarity between this habitat and grassland, in relation to their species abundance and also to their species presence-absence, was the greatest.
\end{abstract}

solitary bees / community / biocenosis / species diversity / trap-nest / Apoidea

\section{INTRODUCTION}

Studies of tropical forest systems have made important contributions to understanding patterns of species diversity and community structure (Ricklefs and Schluter, 1993). Due to increasing global habitat destruction modern studies of diversity are of vital importance for understanding biological communities and their conservation (Purvis and Hector, 2000).

The nature of land-use change in recent decades has not only resulted in a dramatic decrease in total forest cover, but also in an increasingly skewed size-distribution of forest remnants. Forest fragmentation is an important process contributing to the present-day concern over the loss of biodiversity and species extinction rates (Didham et al., 1996; Tscharntke et al., 1998; Steffan-Dewenter et al., 2002).
Some recent studies have shown that the diversity and abundance of several animal taxa in agricultural landscapes decline significantly with increasing distance from native habitats (Klein et al., 2002; Steffan-Dewenter, 2002, 2003; Ricketts, 2004; Schulze et al., 2004). Although these declines might be intuitive and expected from theory (MacArthur and Wilson, 1967), the degree of decline differs widely among taxa (Ricketts et al., 2001).

Several countries such as Brazil, Britain, Canada, S. Africa, and the United States have recently developed initiatives to conserve and protect pollinators, which are declining in many parts of the world (Stubbs and Drumond, 2001). Fragmentation-induced changes in the structure of the pollinator guild may have far-reaching consequences for gene flow in plant populations and for plant and animal community

\footnotetext{
* Corresponding author: isatunes@yahoo.com.br
}

1 Manuscript editor: Jean Noël Tasei 
dynamics (Didham et al., 1996). Bees are probably the most important pollinator group in both number and diversity of pollinated plant species (Didham et al., 1996). It is estimated that there are over sixteen thousand species of bees throughout the world (Michener, 2000). Of these, approximately eighty five percent are solitary and some build their nests in preexisting cavities. Thus, wooden trap nests have been used by biologists for years to lure bees and wasps to make their nests, where they can be easily studied (Krombein, 1967).

More recently, trap nests have also been used to monitor selected bee species through time in several sites to record possible frequency changes and constancy in different habitat type (Frankie et al., 1993; Strickler et al., 1996). These insects can be expected to reflect ecological change through their species richness and related parameters, and ecological functions or interactions: pollination, predation, and mortality due to their natural enemies. In a comparison of habitat types (grasslands and field margins), species richness of trap-nest communities correlated to plant diversity, but percentage mortality, due to parasitism and predation, correlated only to field age (Tscharntke et al., 1998).

The purpose of this study was to monitor the solitary bee fauna caught in trap nests in three different habitats at the Parque Municipal das Araucárias. The main questions addressed in this paper are: Are there significant differences in bee species composition between habitats? Could environmental factors, such as air temperature and humidity, be related to these differences? What is the constancy of selected species in the habitats? Is there any association between the species? What type of association could occur between species?

\section{MATERIALS AND METHODS}

\subsection{Study areas}

This study was carried out at the Parque Municipal das Araucárias, in the municipality of Guarapuava, state of Paraná, southern Brazil $\left(25^{\circ} 23^{\prime} \mathrm{S}-\right.$ $51^{\circ} 27^{\prime} \mathrm{W}, 1.120 \mathrm{~m}$ of altitude (above sea level). This area is characterized by a wet, cool season, and during the warmest months the average temperature is less than $22{ }^{\circ} \mathrm{C}$. Hoar frosts are common and severe in this region.
The landscape in Guarapuava is composed mainly of araucaria forest and grasslands (Veloso et al., 1991). However the grasslands have suffered high anthropic interference and the araucaria forest has been reduced to approximately $5 \%$ of its original size, due to agriculture and wood exploration. The total area of the Parque Municipal das Araucarias is $104 \mathrm{ha}$, comprised of araucaria forest (43 ha), grassland (6.8 ha), swamp (11.1 ha), riparian forest (10.1 ha) and altered areas (33 ha).

Collections were carried out from December 2001 to December 2003 and were concentrated in a very heterogeneous site which included araucaria forests, swamps and grasslands. The grasslands are characterised physionomically by areas of low grasses and no bushes. Species of grasses from Ciperaceae, Fabaceae, Verbenaceae, Asteraceae and Apiaceae families are the main ones found in this habitat. Surrounded by the grasslands are the araucaria forests, in which there is a predominance of Araucaria angustifolia (Coniferae; Araucariaceae). The swamps are located at the lowest regions of the park. These are composed mainly of grasses and Apiaceae.

\subsection{Sampling program}

Nests of solitary bees were obtained using trapnests made by blocks of wood (Araucaria angustifolia) $25 \times 20 \times 120 \mathrm{~mm}$, drilled longitudinally to a depth of $80 \mathrm{~mm}$ with the apertures 7.0, 10.0, and $13.0 \mathrm{~mm}$ in diameter. Before being drilled, the wood blocks were sawed in half longitudinally and then held together with adhesive tape to permit the examination of the cavities when opened. Each nest was placed $1.5 \mathrm{~m}$ above the ground and was inspected every two weeks. In each inspection, all completed nests were removed and immediately replaced with empty traps of the same diameter. The nests were then brought to the laboratory in order to investigate their contents. If eggs and/or larvae were present, the nest was closed to allow the completion of the lifecycle and the emergence of the adults.

Two areas were studied in each habitat, with 2 transects per area and 4 sampling stations per transect. Each sampling station included 12 trap nests, four for each opening diameter (7.0, 10.0 and $13.0 \mathrm{~mm}$, respectively), totaling 576 traps.

Humidity and temperature in each habitat were measured using a digital thermohygrometer, every two weeks. The order in which the habitats were measured was randomized.

\subsection{Statistical analyses}

The species abundance data in the Parque Municipal das Araucarias was illustrated by plotting the number of specimens collected for each species in 
order of its rank, from greatest to least abundance, following Whittaker (1965). Species richness was then estimated by fitting the log-normal distribution (Krebs, 1989; Ludwig and Reynolds, 1988).

Species frequency of occurrence (FO) and species dominance (D) were calculated according to Palma (1975): $\mathrm{FO}=($ Number of sampling with species $\mathrm{i} \div$ Number of sampling) $\times 100$. If $\mathrm{FO} \geq 50 \%$, the species is termed a primary species; if $50 \% \geq$ $\mathrm{FO} \geq 25 \%$, the species is termed a secondary species; if $25 \% \geq \mathrm{FO}$, the species is termed an incidental species. $\mathrm{D}=$ (Abundance of species $\mathrm{i} \div$ total abundance $)$ $\times 100$. If $\mathrm{D}>5 \%$ the species is termed a dominant species; if $2.5 \%<\mathrm{D}<5 \%$ the species is termed an accessory species; if $\mathrm{D}<2.5 \%$ the species is termed an incidental species. Palma (1975) reported that these indices together can be used to group the species into three categories: common species, intermediate species, and rare species.

The association between species was also investigated, using Jaccard's index (Ludwig and Reynolds, 1988). Species diversity was calculated using three indices: species richness (Margalef's index), Shannon-Wiener diversity and species evenness (Pielou's J index) (Ludwig and Reynolds, 1988). To calculate the differences and similarities between the habitats, $\alpha$-diversity for each of them was measured using Shannon-Wiener's index. A posteriori Statistic T-test was carried out in order to analyze the null hypothesis of no difference between the ShannonWiener's values (Magurran, 2004).

To investigate the changes in species composition between habitat partitions ( $\beta$-diversity) they were grouped by their abundance using the chord distance coefficient, from relative euclidian distance indices, as a metric and the unweighted pair group method average (UPGMA) as the clustering method (Ludwig and Reynolds, 1988). A simple discriminant analysis (SDA) was carried out to test the significant differences in air temperature and humidity between communities delimited by cluster classification (Ludwig and Reynolds, 1988).

Considering the Parque Municipal das Araucárias as the measure unit, $\gamma$-diversity was calculated using Shannon-Wiener's index. This diversity index can be used to compare biotopes with the same dimensions.

Jaccard's index was also used to measure the similarity among the habitats in relation to presenceabsence of species (Ludwig and Reynolds, 1988).

\section{RESULTS}

\subsection{Species abundance and dominance}

The abundance of each species in a trapnesting bee community was illustrated by plot-

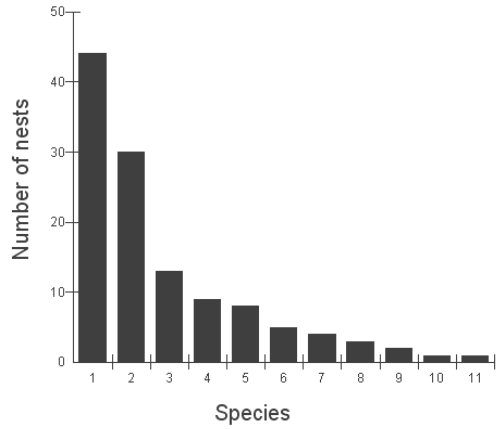

Figure 1. Whittaker plot for species nest abundance of trap-nesting bees. 1: Centris tarsata, 2: Megachile brasiliensis, 3: Colletes sp, 4: Epanthidium nectarinioides, 5: Megachile (D.) $\mathrm{sp}_{1}, 6$ : Anthodioctes claudii, 7: Megachile $\mathrm{sp}_{1}$ 8: Megachile $\mathrm{sp}_{2} 9$ : Megachile (A.) fiebrigi, 10: Xylocopa augusti, 11: Megachile (Moureapis) $\mathrm{sp}_{1}$.

ting the number of specimens collected for each species in order of its rank, from greatest to least abundance (Whittaker plot, Fig. 1). One hundred and twenty solitary bee nests, belonging to eleven species of Megachilidae (72.7\%), Apidae (18.2\%) and Colletidae (9.1\%) families, were collected.

The most abundant species were Centris (Hemisiella) tarsata with 44 nests (37\%), Megachile (Melanosaurus) brasiliensis with 30 nests $(25.2 \%)$ and Colletes sp with 13 nests $(10.9 \%)$ (Fig. 1). Intermediate species were $C$. tarsata $(\mathrm{D}=36.67 \% ; \mathrm{FO}=26.92 \%)$, M. brasiliensis $(\mathrm{D}=25.00 \% ; \mathrm{FO}=23.08 \%)$, Colletes $\mathrm{sp}(\mathrm{D}=$ $10.83 \%$; $\mathrm{FO}=15.39 \%)$, Epanthidium nectarinioides $(\mathrm{D}=7.50 \% ; \mathrm{FO}=11.54 \%)$, Megachile (Dactylomegachile $) \mathrm{sp}_{1}(\mathrm{D}=6.67 \% ; \mathrm{FO}=$ $11.54 \%)$. Anthodioctes claudii $(\mathrm{D}=4.17 \%$; $\mathrm{FO}=9.62 \%)$, Me gachile $\mathrm{sp}_{1}(\mathrm{D}=3.33 \% ; \mathrm{FO}=$ $5.77 \%)$ and Megachile $\mathrm{sp}_{2}(\mathrm{D}=2.5 \% ; \mathrm{FO}=$ $5.77 \%$ ). Megachile (Austramegamegachile) fiebrigi $(\mathrm{D}=1.67 \% ; \mathrm{FO}=3.85 \%)$, Xylocopa $($ Neoxylocopa) augusti $(\mathrm{D}=0.83 \% ; \mathrm{FO}=1.92 \%)$ and Megachile (Moureapis) $\mathrm{sp}_{1}(\mathrm{D}=0.83 \% ; \mathrm{FO}=$ $1.92 \%)$ were the rare species.

Anthodioctes claudii and M. (Moureapis) $\mathrm{sp}_{1}$ were found only in araucaria forest, $\mathrm{Meg}$ achile $\mathrm{sp}_{2}$ only in swamp and $X$. augusti only in grassland. On the other hand, C. tarsata, $M$. brasiliensis, Colletes sp, E. nectarinioides and $M$. (Dactylomegachile) $\mathrm{sp}_{1}$ were found in both swamp and grassland areas. Only $\mathrm{Meg}$ achile $\mathrm{sp}_{1}$ was found in araucaria forest and 
Table I. Number of trap-nesting bee species and their nests abundance in three habitats in the Parque Municipal das Araucárias.

\begin{tabular}{|c|c|c|c|}
\hline \multirow[b]{2}{*}{ SPECIES } & \multicolumn{3}{|c|}{ HABITAT } \\
\hline & $\overline{\text { swamp }}$ & assland & $\begin{array}{c}\text { araucaria } \\
\text { forest }\end{array}$ \\
\hline \multicolumn{4}{|l|}{ Apidae } \\
\hline Centris tarsata Smith & 13 & 31 & 0 \\
\hline $\begin{array}{l}\text { Xylocopa augusti } \\
\text { Lepeletier }\end{array}$ & 0 & 1 & 0 \\
\hline \multicolumn{4}{|l|}{ Megachilidae } \\
\hline $\begin{array}{l}\text { Megachile brasiliensis } \\
\text { Dalla Torre }\end{array}$ & 29 & 1 & 0 \\
\hline Megachile $\mathrm{sp}_{1}$ & 0 & 1 & 3 \\
\hline Megachile $\mathrm{sp}_{2}$ & 3 & 0 & 0 \\
\hline $\begin{array}{l}\text { Megachile (A.) fiebrigi } \\
\text { Schrottky }\end{array}$ & 1 & 0 & 1 \\
\hline Megachile $(M.) \mathrm{sp}_{1}$ Raw & 0 & 0 & 1 \\
\hline $\begin{array}{l}\text { Megachile (D.) } \mathrm{sp}_{1} \\
\text { Mitchell }\end{array}$ & 6 & 2 & 0 \\
\hline $\begin{array}{l}\text { Anthodioctes claudii } \\
\text { Urban }\end{array}$ & 0 & 0 & 5 \\
\hline $\begin{array}{l}\text { Epanthidium } \\
\text { nectarinioides Schrottky }\end{array}$ & 8 & 1 & 0 \\
\hline \multicolumn{4}{|l|}{ Colletidae } \\
\hline Colletes sp & 3 & 10 & 0 \\
\hline Nests number & 63 & 47 & 10 \\
\hline Species number & 7 & 7 & 4 \\
\hline
\end{tabular}

grassland and $M$. (A.) fiebrigi in araucaria forest and swamp (Tab. I).

\subsection{Species association}

The hypothesis of no association between the species was accepted $(\mathrm{W}=5.51$; variance ratio was 2.28 , essentially equal to the expected value of 1.0 under the null hypothesis of no associations $(0.5<P<0.1)$.

\subsection{Species diversity}

The number of species found in swamp $(\mathrm{S}=$ 7) and in grassland $(S=7)$ was similar and they were higher than in araucaria forest $(S=4)$. In relation to nest abundance (total number of trap
Table II. Abundance (A), richness $\left(D_{M g}\right)$, diversity $\left(\mathrm{H}^{\prime}\right)$ and evenness $\left(\mathrm{J}^{\prime}\right)$ index of trap-nesting bees in three habitats in the Parque Municipal das Araucárias.

\begin{tabular}{lcccc}
\hline HABITAT & $\mathrm{A}$ & $\mathrm{H}^{\prime}$ & $\mathrm{D}_{\mathrm{Mg}}$ & $\mathrm{J}^{\prime}$ \\
\hline araucaria forest & 10 & 0.507 & 3.00 & 0.843 \\
swamp & 63 & 0.662 & 3.34 & 0.784 \\
grassland & 47 & 0.463 & 3.59 & 0.548 \\
\hline
\end{tabular}

nests occupied), they were higher in swamp ( $\mathrm{n}=$ $63)$ than in grassland $(n=47)$ and araucaria forest $(n=10)($ Tab. I). $\alpha$-diversity in swamp was significantly greater than in araucarias forest $(\mathrm{t}=4.497 ; P<0.001)$ and grassland $(\mathrm{t}=2.636$; $P<0.01)$. Although Shannon-Wiener's index showed a greater $\alpha$-diversity in araucaria forest than in grassland (Tab. II), it was not significantly different $(0.753 ; 0.5>P>0.2)$. In relation to species evenness, araucaria forest showed a greater value $\left(\mathrm{J}^{\prime}=0.843\right)$ than swamp $\left(J^{\prime}=0.784\right)$ and grassland $\left(J^{\prime}=0.548\right)$. On the other hand, grassland showed greater species richness $\left(D_{M g}=3.59\right)$ than swamp $\left(D_{M g}=\right.$ 3.34) and araucaria forest $\left(\mathrm{D}_{\mathrm{Mg}}=3.00\right)$.

The estimated species richness for the Parque Municipal das Araucárias as fitted by lognormal distribution was of 12 species. $\gamma$ - diversity value for the Parque Municipal das Araucárias was H' $=0.789$.

\subsection{Habitat similarity}

In relation to presence-absence of species in the three habitats, the similarity between swamp and grassland areas was the highest $(\mathrm{J}=0.625)$. The similarities between swamp and araucaria forest $(\mathrm{J}=0.100)$ and between araucaria forest and grassland $(\mathrm{J}=0.100)$ were similar.

$\beta$-diversity can be represented by a dendrogram (Fig. 2). It is possible to see that the greatest similarity, in relation to species abundance, occurred between swamp and grassland areas. On the other hand, araucaria forest was the habitat with the greatest dissimilarity. Despite the air temperature in araucaria forest being significantly lower than in swamp and grassland $(\mathrm{F}=$ 5.3676; $P=0.0002 ; \mathrm{n}=47)$ and its air humidity significantly higher $(\mathrm{F}=4.8689 ; P=0.0005$; $\mathrm{n}=47$ ) (Figs. 3, 4), by discriminant analysis the Mahalanobis distance was not significant 


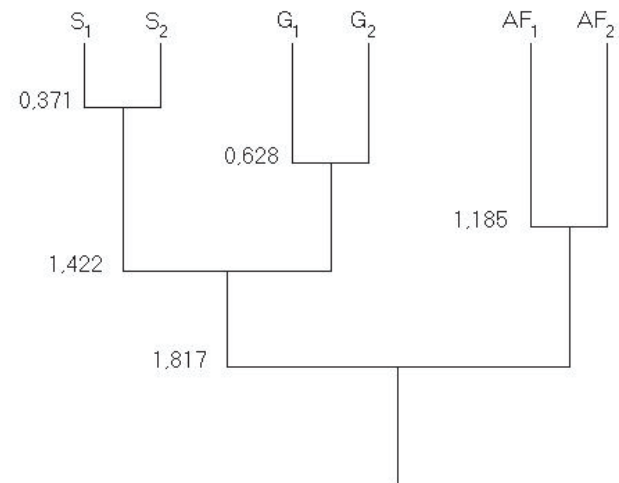

Figure 2. Dissimilarity dendrogram between the habitats related to their bees abundance. $\mathrm{S}_{1}$ : swamp 1. $S_{2}$ : swamp 2; $G_{1}$ : grassland $1 ; G_{2}$ : grassland 2 ; $\mathrm{AF}_{1}$ : araucaria forest $1 ; \mathrm{AF}_{2}$ : araucaria forest 2 .

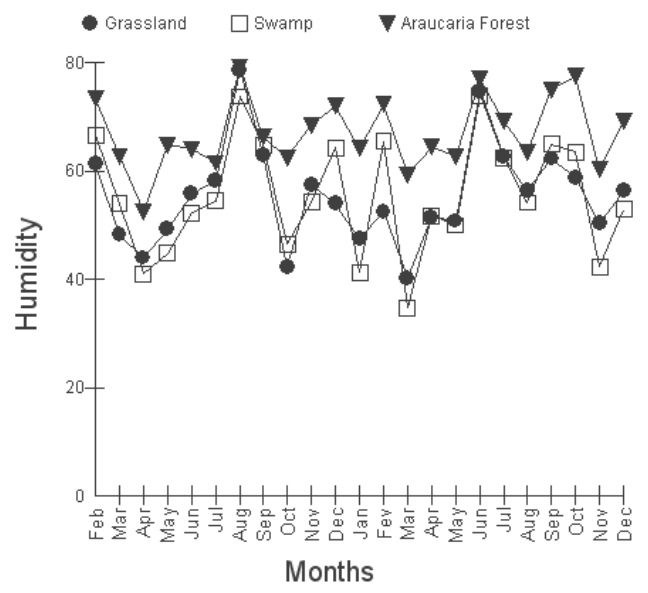

Figure 3. Air humidity conditions (\%) in different habitats from February 2002 to December 2003.

( $\mathrm{F}=8.329$ at $\mathrm{df}=2,3 ; P>0.05)$. Thus, these two environmental variables were not found to be significantly different between the two groups and could not be used to distinguish between them.

\section{DISCUSSION}

Overall, my results indicate that there was a significant difference in the diversity of cavitynesting bees between the swamp and the other

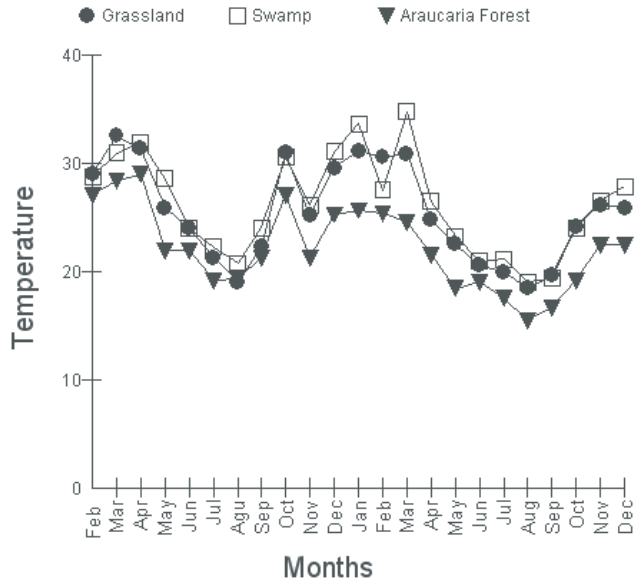

Figure 4. Air temperature $\left({ }^{\circ} \mathrm{C}\right)$ in different habitats from February 2002 to December 2003.

two habitats. However, by Cluster analysis the swamp and grassland were more similar in relation to species abundance and species presence-absence as measured by Jaccard's index. This might be due to similarities between the two habitats, such as insulation ratio, since air temperature and humidity were not found to be significantly different between the two groups and could not be used to distinguish between them. Perez-Maluf (1993), Camillo et al. (1995) and Aguiar and Martins (2002) also found a high bee nesting activity in disturbed and open areas here in Brazil.

Another similarity between swamp and grassland areas is probably the greater availability of flower resources. Fye (1972) noticed that in disturbed and open areas the activity of trap-nesting bees was more pronounced than in continuous forest. According to the author these areas were colonized by pioneer plant species that represented an important food resource for these insects and, consequently, their populations increased. Diverse vegetation obviously supplies a greater amount of nutritious pollen, thereby supporting more bee species (Gathmann et al., 1994). Bees need much less time to provision their nests in the diverse vegetation of naturally developed fields than in the uniform environment of sown fields (Tscharntke et al., 1998).

An important factor that can probably affect the sampling of cavity-nesting bees, and consequently their diversity index, is the natural 
nest sites in the habitat. Since the use of artificial nests is random, perhaps the greater availability of natural substratum for nesting can decrease the rate of trap-nest occupation (Viana et al., 2001). Coville and Coville (1980) observed this tendency in Costa Rican habitats where the number of natural nests was greater. As such, we need to cover this point in order to interpret diversity index results. In this study the low species richness and abundance in Araucaria forest might have been influenced by this factor as well as by the lack of vertical variation in the sample, since bees were trapnested only at $1.5 \mathrm{~m}$ above the ground. Morato and Campos (2000) observed that species diversity was significantly greater in continuous forest and natural gaps than in deforested areas in Central Amazonia. Morato (2001) investigated the effects of forest fragmentation on the patterns of vertical abundance and richness of solitary bee communities and found that in both continuous primary forest and isolated forest fragments, bee species richness at $15 \mathrm{~m}$ was almost twice that at $1.5 \mathrm{~m}$ above the ground. According to Roubik (1982) this pattern is probably due the great availability of canopy flowers resource. Wolda and Roubik (1986) noticed some bee species flying at different heights in tropical forests. Thus, the fact that all of my traps were located at a height of $1.5 \mathrm{~m}$ may have limited the number of species I collected.

The number of species ( $\mathrm{S}=11$ ) sampled in this study and the one estimated by lognormal distribution $(S=12)$ were very similar to that found by Morato and Campos (2000) in Brazilian Central Amazonia ( $\mathrm{S}=14)$ and higher than those found by Viana et al. (2001) $(\mathrm{S}=7)$ and Aguiar and Martins (2002) $(\mathrm{S}=8)$ in the states of Bahia and Paraíba northern Brazil, respectively. In relation to nest abundance, a total of 405 bee nests were collected by Morato and Campos (2000). This number was three times higher than that collected at the Parque Municipal das Araucárias, but the total monitored area in his study (122 ha of forest fragments, natural gaps and deforested areas) was also more extensive than that in mine ( 43 ha of araucarias forest, 6.8 ha of grassland and 11.1 ha of swamp). Aguiar and Martins (2002) also collected in a larger area (3 994.2 ha) and the nest abundance was 138 , very similar to that registered in the present study. On the other hand, the total number of nests sampled by Viana et al. (2001) was almost half that of the present study $(n=62)$, although the authors did not report the total sampled area, in their study.

According to Heithaus (1979) differences in sample sizes as well as the sizes of the sampled areas may account for some of the differences between species richness of temperate and tropical areas. Comparing species richness among assemblages using different sample sizes may produce erroneous conclusions due to the strong positive relationship between richness and sample size (Melo et al., 2003). The species richness data discussed here are, presumably, dependent upon the area sampled as well as sample intensity, but it is possible to suggest that both species richness and diversity were greater in the Parque Municipal das Araucarias than in all those regions, since the sampling effort of my study was the smallest and the species richness and their abundance was very similar to those registered by these authors. Moreover, we can notice a bee richness pattern that has been documented in the literature, that these insects are most abundant in semi-deserts and temperate areas (Silveira et al., 2002). In South America the bee species richness increases from the Savannas to Grassland in the south of Brazil and, in Argentina's semi-desert regions (Michener, 1979). All these investigated Brazilian regions are tropical with the exception of Guarapuava which is subtropical. It is located at $1120 \mathrm{~m}$ above sea level and has been considered one of the coldest cities in the state of Parana.

Several hypotheses have been proposed to explain the low bee diversity in tropical regions (Silveira et al., 2002). One of them, proposed by Roubik cited by Michener (1979), suggests that these regions are inhabited by a larger number of eusocial species than subtropical and temperate regions. Each one of these eusocial species forms populous colonies which are composed mostly of works that lead their nestmates to rich food resources, which are in time exhausted. Thus, they could be the main factor responsible for species richness reduction in the tropics.

The distribution of bee families also seem to be related to latitudinal gradients. In the Neotropical region, Anthophoridae (sensu stricto) and Apidae have a great proportion of species in tropical areas, and the abundance of Halictidae 
species increases with higher latitudes in southern Brazil and in disturbed areas (Laroca et al., 1982). On the other hand, the proportion of Megachilidae can fluctuate in different sites since it was high in both southern Brazil (Wittmann and Hoffman, 1990) and near to Ecuador (Roubik, 1989). In the present study bees belonging to the family Megachilidae were the predominant group. Frankie et al. (1998) monitored bee species in wooden trap nests in six sites in northern Central California, during 3 years, and found that all bees belonged to this family. Different results, related to Megachilidae species abundance, have been found in some Brazilian tropical region (Perez-Maluf, 1993; Aguiar and Martins, 2002; Morato and Campos, 2000; Viana et al., 2001).

Centris tarsata was the most abundant species trapped during this study as well as in those carried out by Perez-Maluf (1993), Viana et al. (2001) and Aguiar and Martins (2002). Nevertheless, $M$. brasiliensis, the second most abundant species, and all the other species, were not recorded in the monitoring carried out by these authors and by Morato and Campos (2000) and Morato (2001). Garófalo et al. (2004) reported that members of the families Apidae and Megachilidae have been frequent in wood traps, but $M$. brasiliensis was not present in their list of species caught in trap nests in some studies performed in Brazil.

All the results presented in my study reflected that trap nests can be a useful tool, not only for studies on the biology and development of solitary species of bees, but also for investigating species assemblages and community structure. By this technique it was possible to find the common pattern of communities, with some intermediate and rare species, and a bee richness pattern consistent with that previously documented for South America.

\section{ACKNOWLEDGEMENTS}

Partial funding support was provided by Fundação Araucária (The State of Paraná Research Foundation) and UNICENTRO (Guarapuava, PR, Brazil). We thank Prof. Dr. Miguel Petrere Jr. from UNESP (Rio Claro-SP, Brazil) for statistical discussion. We also thank Prof. Dr. Gabriel Augusto R. Melo and Profa Dra. Danuncia Urban from UFPR (PR, Brazil) for bees identification and Prof Ms Sérgio Bazílio from UNICENTRO (PR, Brazil) for some help.
Résumé - Diversité des espèces et structure de la biocénose chez les abeilles nidifiant dans des pièges dans le sud du Brésil. Le but de cette étude était de recenser la faune d'abeilles solitaires qui nidifie dans des cavités pré-existantes dans trois habitats différents du Parque Municipal das Araucarias (état du Parana, Brésil). Les principales questions abordées dans cet article sont : la composition des espèces d'abeilles varie-t-elle de façon significative entre les trois habitats? Des facteurs du milieu, tels que la température et l'humidité de l'air, peuvent-ils être en relation avec ces différences ? Les abeilles sélectionnées sont-elles constantes dans les habitats ? Y a-t-il une quelconque association entre les espèces ? Les nids de ces insectes ont été obtenus en disposant à $1,50 \mathrm{~m}$ du sol des pièges à nidification de $7,0,10,0$ et $13 \mathrm{~mm}$ de diamètre et de $80 \mathrm{~mm}$ de profondeur. Ils ont été inspectés tous les 15 jours. Les récoltes ont été faites de décembre 2001 à décembre 2003 dans un site très hétérogène comprenant des forêts d'araucarias, des marécages et des prairies. La diversité des espèces a été calculée à partir de l'abondance et de la constance des espèces et de l'indice ShannonWiener. Pour calculer les différences et les similitudes entre les habitats, la diversité de chacun d'eux a été mesurée par l'indice Shannon-Wiener. La diversité $\beta$ a été calculée pour évaluer les variations de composition des espèces entre les subdivisions des habitats. Une analyse de groupement et des dendogrammes ont été élaborés à partir de ces résultats. Une analyse discriminante simple (SDA) a été faite pour tester les différences significatives de la température et de l'humidité de l'air entre communautés délimitées par la classification de groupement. Mais la distance de Mahalanobis n'étant pas significative dans cette analyse, ces deux variables du milieu n'ont pu être utilisées pour distinguer les habitats. La diversité a été calculée par l'indice de ShannonWiener. Cent vingt nids d'abeilles solitaires, appartenant à 11 espèces de Megachilidae $(72,7 \%)$, d'Apidae $(18,2 \%)$ et de Colletidae $(9,1 \%)$ ont été récoltés. Les espèces les plus abondantes étaient: Centris (Hemisiella) tarsata, Megachile (Melanosaurus) brasiliensis, Colletes sp, and Megachile (Dactylomegachile) $\mathrm{sp}_{1}$, les intermédaires C. tarsata, M. brasiliensis, Colletes sp, Epanthidium nectarinioides, Megachile (Dactylomegachile) $\mathrm{sp}_{1}$, Anthodioctes claudii, Megachile $\mathrm{sp}_{1}$ et les plus rares Megachile $\mathrm{sp}_{2}$. Megachile (Austramegamegachile) fiebrigi, Xylocopa (Neoxylocopa) augusti et Megachile (Moureapis) $\mathrm{sp}_{1}$. On n'a pas trouvé d'espèces communes lors de cette étude. Aucune association significative entre les espèces n'a été notée. Le marécage a fourni l'abondance et la diversité d'espèces la plus grande. C'est entre le marécage et la prairie que la similitude, en termes d'abondance d'espèces et aussi de présence-absence d'espèces, a été la plus grande.

Apoidea / abeille solitaire / diversité écologique / biocénose / piège à nidification 
Zusammenfassung - Artenvielfalt und Vergesellschaftungsstruktur in Fallen nistenden Bienen im südlichen Brasilien. Ziel dieser Untersuchung war in drei verschiedenen Habitaten des Parque Municipal das Araucárias die in vorgefundenen Höhlungen lebende Fauna solitärer Bienen zu erfassen. Die in dieser Untersuchung hauptsächlich angesprochenen Fragen waren: Gibt es signifikante Unterschiede in der Zusammensetzung der Bienenarten an den verschiedenen Habitaten? Können Umgebungsvariable wie Lufttemperatur und Feuchtigkeit zu diesen Unterschieden in Beziehung gesetzt werden? Sind ausgewählte Arten in den Habitaten konstant? Gibt es Assoziationen zwischen den Arten? Nester dieser Insekten wurden durch die Verwendung von Fallennestern mit 7,0, 10,0, and $13 \mathrm{~mm}$ Durchmesser und $80 \mathrm{~mm}$ Tiefe gewonnen. Jedes Nest wurde 1,5 m über Bodenhöhe angebracht und alle 2 Wochen untersucht. Die Nestsammlungen wurden von Dezember 2001 bis Dezember 2003 durchgeführt und wurden in einem sehr heterogenen Gelände durchgeführt, das Araukarienwälder, Moore und Grasland einschloss. Zur Beschreibung der Artenvielfalt und der Unterschiede oder Ähnlichkeit der Habitate wurden Indizes der Reichhaltigkeit und Eveness berechnet. Die Diversität wurde für jeden Standort anhand des Shannon-Wiener Index berechnet. Um Änderungen der Artenzusammensetzung zwischen Unterteilungen der Habitate zu erfassen, wurde die Diversität berechnet. Auf Grundlage dieser Ergebnisse wurden Klusteranalysen und Dendrogramme erstellt. Eine einfache Diskriminanzanalyse (SDA) wurde als Test auf signifikante Unterschiede in der Lufttemperatur und Feuchtigkeit zwischen den durch Klusterklassifikation abgegrenzten Gesellschaften durchgeführt. Da der Mahalanobisabstand in dieser Analyse nicht signifikant war, konnten diese Variablen zur Unterscheidung der Habitate nicht herangezogen werden. Die Diversität wurde unter Nutzung des Shannon-Wiener Index berechnet. Einhundertundzwanzig Nester von solitären Bienen wurden gesammelt, diese gehörten 11 Arten der Megachilidae (72,7\%), Apidae (18,2\%) und Colletidae $(9,1 \%)$ an. Die häufigsten Arten waren Centris (Hemisiella) tarsata, Megachile (Melanosaurus) brasiliensis, Colletes sp, und Megachile (Dactylomegachile) $\mathrm{sp}_{1}$. Arten mittlerer Häufigkeit waren C. tarsata, M. brasiliensis, Colletes sp, EpaAnthidium nectarinioides, Megachile (Dactylomegachile) $\mathrm{sp}_{1}$, Anthodioctes claudii, Megachile $\mathrm{sp}_{1}$, die seltenen Arten waren Megachile $\mathrm{sp}_{2}$. Megachile (Austramegamegachile) fiebrigi, Xylocopa (Neoxylocopa) augusti und Megachile (Moureapis) $\mathrm{sp}_{1}$. Gemeinsame Spezies wurden in der Studie nicht gefunden und es gab keine Assoziationen zwischen den Spezies. Die Moore zeigten die größte Vorkommenshäufigkeit und Diversität. Die Ähnlichkeit zwischen diesem Habitat und dem Grassland war in Beziehung auf die Artenvielfalt als auch bezüglich des Vorkommens oder Nichtvorkommens der Arten am höchsten.
Solitäre Bienen / Gesellschaften / Diversität / Fallennester / Apoidea

\section{REFERENCES}

Aguiar A.J.C., Martins C.F. (2002) Abelhas e vespas solitárias em ninhos-armadilha na Reserva Biológica Guaribas (Mamanguape, Paraíba, Brasil), Rev. Bras. Zool. 19, 101-116.

Camillo E., Garofalo C.A., Serrano J.C., Muccillo G. (1995) Diversidade e abundância sazonal de abelhas e vespas solitárias em ninhos armadilhas (Hymenoptera, Apocrita, Aculeata), Rev. Bras. Biol. 39, 459-470.

Coville R.E., Coville P.L. (1980) Nesting biology and male behaviour of Trypoxylon (Trypargilum) tenoctitlan in Costa Rica (Hymenoptera: Sphecidae), Ann. Entomol. Soc. Am. 73, 110-119.

Didham R.K., Ghazoul J., Stork N.E, Davis A.J. (1996) Insects in fragmented forests: a functional approach, Trends Ecol. Evol. 11, 255-260.

Frankie G.W., Newstron L.E., Vinson S.B., Barthell J.F. (1993) Nesting-habitat preferences of selected Centris bee species in Costa Rican Dry forest, Biotropica 25, 322-333.

Frankie G.W., Thorp R.W., Newstrom-LLoyd L.E., Rizzardi M.A., Barthell J.F., Griswold T.L., Kin J.-Y., Kappagoda S. (1998) Monitoring solitary bees in modified wildland habitats: implications for bee ecology and conservation, Environ. Entomol. 27, 1137-1148.

Fye R.E. (1972) The effect of forest disturbances on populations wasps and bees in Northwestern Ontario (Hymenoptera: Aculeata), Can. Entomol. 104, 1623-1633.

Garófalo C.A., Martin C.F., Alves Dos Santos I. (2004) The brazilian solitary bee species caught in trap nests, in: B.M. Freitas, J.O. Pereira (Eds.), Solitary Bees, Conservation, Rearing and Management for Pollination, Imprensa Universitária, Fortaleza, pp. 77-84.

Gathmann A., Greiler H.J., Tscharntke T. (1994) Trapnesting bees and wasps colonizing set-aside fields: succession and body size, management by cutting and sowing, Oecologia 98, 8-14.

Heithaus E.R. (1979) Community structure of neotropical flower visiting bees and wasps: diversity and phenology, Ecology 60, 190-202.

Klein A.M., Steffan-Dewenter I., Tscharntke T. (2002) Effects of land-use intensity in tropical agroforestry systems on flower-visiting and trap-nesting bees and wasps, Conserv. Biol. 16, 1003-1014.

Krebs C.J. (1989) Ecological Methodology, Harper and Row, New York.

Krombein K.V. (1967) Trap-nesting Wasps and Bees Life Histories, Nests and Associates, Smithsonian Press, Washington.

Laroca S., Cure J.R., Bortoli C. (1982) A associação de abelhas silvestres (Hymenoptera, Apoidea) de 
uma área restrita no interior da cidade de Curitiba (Brasil): uma abordagem biocenótica, Dusenia 17, 93-117.

Ludwig J.A., Reynolds J.F. (1988) Statistical ecology: a primer on methods and computing, John Wiley and Sons, New York.

MacArthur R.H., Wilson E.O. (1967) The theory of island biogeography, Princeton University Press, Princeton, New Jersey.

Magurran A.E. (2004) Measuring Biological Diversity, Blackwell Science, Oxford.

Melo A.S., Pereira R.A.S., Santos A.J., Shepherd G.J., Machado G., Medeiros H.F., Sawaya R. (2003) Comparing species richness among assemblages using sample units: why not use extrapolation methods to standardize different sample sizes? Oikos 101, 398-410.

Michener C.D. (1979) Biogeography of the bees, Ann Missouri Bot. Gard. 66, 277-347.

Michener C.D. (2000) The bees of the world, The Johns Hopkins University Press, Baltimore.

Morato E.F. (2001) Efeitos da fragmentação florestal sobre vespas e abelhas solitárias em uma área da Amazônia Central. II Estratificação vertical, Rev. Bras. Zool. 18, 727-747.

Morato E.F., Campos L.A. (2000) Efeitos da fragmentação florestal sobre vespas e abelhas solitárias em uma área da Amazônia Central, Rev. Bras. Zool. 17, 429-444.

Palma S. (1975) Contribución al estudio de los sifonoforos encontrados frente a la costa de Valparaiso. Aspectos ecológicos, in: II Simpósio Latinoamericano sobre Oceanografia Biológica, Univ. D’Oriente, Venezuela 2, pp. 119-133.

Péres-Maluf R. (1993) Biologia de vespas e abelhas solitárias, em ninhos-armadilhas, em Viçosa-MG, M.S. thesis, Universidade Federal de Viçosa, Viçosa, Minas Gerais, Brasil.

Purvis A., Hector A. (2000) Getting the measure of biodiversity, Nature 405, 212-219.

Ricketts T.H. (2004) Tropical Forest Fragments Enhance Pollinator Activity in Nearby Coffe Crops, Conserv. Biol. 18, 1262-1271.

Ricketts T.H., Daily G.C., Ehrlich P.R., Fay J.P. (2001) Country-side biogeography of moths in a fragmented landscape: biodiversity in native and agricultural habitats, Conserv. Biol. 15, 378-388.

Ricklefs R., Schluter D. (1993) Species diversity in ecological communities, University of Chicago Press, Chicago.

Roubik D.W. (1982) Ecological impact of Africanized honeybees on native neotropical pollinators, in: Jaisson P. (Ed.), Social Insects in the Tropics, Université Paris-Nord, Paris, pp. 233-247.
Roubik D.W. (1989) Ecology and natural history of tropical bees, Cambridge University Press, Cambridge.

Schulze C.H., Waltert M., Kessler P.J.A., Pitopang R., Shahabuddin, Veddeler D., Mühlenberg M., Gradstein S.R., Lleuschner C., Steffan-Dewenter I., Tscharntke T. (2004) Biodiversity indicator groups of tropical land-use systems: comparing plants, birds, and insects, Ecol. Appl. 14, 13211335.

Silveira F.A., Melo G.A.R., Almeida E.A.B. (2002) Abelhas Brasileiras: Sistemática e Identificação, Idmar, Belo Horizonte.

Steffan-Dewenter I. (2002) Landscape context affects trap-nesting bees, wasps, and their natural enemies, Ecol. Entomol. 27, 631-637.

Steffan-Dewenter I. (2003) Importance of habitat area and landscape context for species richness of bees and wasps in fragmented orchard meadows, Conserv. Biol. 17, 1036-1044.

Steffan-Dewenter I., Münzenberg U., Bürger C., Thies C., Tscharntke T. (2002) Scale-dependent effects of landscape context on three pollinator guilds, Ecology 83, 1421-1432.

Strickler K., Scott V.L., Fischer R.L. (1996) Comparative nesting ecology of two sympatric leafcutting bees that differ in body size (Hymenoptera: Megachilidae), J. Kans. Entomol. Soc. 69, 26-44.

Stubbs C.S., Drummond F.A. (2001) Bees and Crop Pollination-Crisis, Crossroads, Conservation, Thomas Say Publ. in Entomology: Proceedings, Entomological Society of America, Lanhan, MD, $156 \mathrm{p}$.

Tscharntke T., Gathmann A., Steffan-Dewenter I. (1998) Bioindication using trap-nesting bees and wasps and their natural enemies: community structure and interactions, J. Appl. Ecol. 35, 708719.

Veloso H.P., Filho A.L., Lima J.C.A. (1991) Classificação da Vegetação Brasileira. Adaptada a um Sistema Universal. Instituto Brasileiro de Geografia - IBGE, Rio de Janeiro, RJ.

Viana B.F., Silva F.O., Kleinert A.M.P. (2001) Diversidade e sazonalidade de abelhas solitárias (Hymenoptera: Apoidea) em dunas litorâneas no nordeste do Brasil, Neotrop. Entomol. 30, 245251.

Whittaker R.H. (1965) Dominance and diversity in land plant communities, Science 147, 250-260.

Wittmann D., Hoffman M. (1990) Bees of Rio Grande do Sul, Southern Brazil (Insecta, Hymenoptera, Apoidea), Iheringia, Sér. Zool. 70, 17-43.

Wolda H., Roubik D.W. (1986) Nocturnal bee abundance and seasonal bee activity in a Panamaniam forest, Ecology 67, 426-433. 